\title{
A RISK-INFORMED APPROACH TO COASTAL ZONE MANAGEMENT
}

\author{
R.B. Jongejan ${ }^{1,2}$, R. Ranasinghe ${ }^{2,3}$, and J.K. Vrijling ${ }^{2}$ \\ Economic and population growth have led to an unprecedented increase in the value at risk in coastal zones over the \\ last century. To avoid excessive future losses, particularly in the light of projected climate change impacts, coastal \\ zone managers have various instruments at their disposal. These primarily concern land-use planning (establishing \\ buffer zones) and engineering solutions (beach nourishment and coastal protection). In this paper, we focus on risk \\ mitigation through the implementation of buffer zones (setback lines). Foregoing land-use opportunities in coastal \\ regions and protecting coasts is costly, but so is damage caused by inundation and storm erosion. Defining appropriate \\ setback lines for land-use planning purposes is a balancing act. It is however unclear what level of protection is \\ facilitated by current approaches for defining setback lines, and whether this is, at least from an economic perspective, \\ sufficient. In this paper, we present an economic model to determine which setback lines would be optimal from an \\ economic perspective. The results provide a useful reference point in the political debate about the acceptability of \\ risk in coastal zones. The main conclusions are (i) that it is useful to define setback lines on the basis of their \\ exceedance probabilities, (ii) that the exceedance probability of an economically efficient setback line will typically \\ be in the order of magnitude of 1/100 per year, (iii) that it is important to distinguish between situations in which \\ morphological conditions are stationary and non-stationary, and (iv) that long-term uncertainties (e.g. due to climate \\ change) influence the exceedance probability of efficient setback lines but only to a limited extent.
}

Keywords: setback line, climate change, sea level rise, coastal protection, coastal risk, coastal hazard

\section{Introduction}

The establishment of coastal setback lines is an effective coastal zone management strategy representing the 'retreat' and/or 'accommodate' philosophies. The coastal zone is the most heavily populated and developed land zone in the world. Nicholls et al. (2007) estimated that $23 \%$ of the global population lives within $100 \mathrm{~km}$ and less than $100 \mathrm{~m}$ above sea level. Of the world's 39 major metropolises with over 5 million inhabitants, 23 are within $100 \mathrm{~km}$ of the coast. Of the world's 16 cities of over 10 million inhabitants, 12 are within $100 \mathrm{~km}$ of the coast. However, accelerated coastal erosion due to climate change is a major threat to coastal communities and assets worldwide. The insatiable human attraction to the coast has resulted in rapid expansions in settlements, urbanization, infrastructure, economic activities and tourism in the 20th century and is likely to continue to increase in the 21 st century. Therefore, the establishment of effective setback lines is now a more delicate issue than it has ever been. Effective setback lines should not only ensure the safety of coastal communities and infrastructure but also ensure that multi-million dollar land use opportunities are not forgone.

Coastal setback lines have historically been determined by separately estimating erosion due to storms, ambient long term recession trends (e.g. due longshore transport gradients), recession due to sea level rise (SLR). Generally, the various components are estimated using a variety of methods such as aerial photogrammetry, numerical modelling, analytical methods, field data etc. and added up to obtain a single deterministic estimate of the setback line. Obviously this approach has several limitations. These include: not taking into account non-linear interactions/linkages amongst various processes (e.g. extreme storm erosion and long term shoreline trends), double counting (e.g. long term recession due to SLR and due to longshore transport gradients), data aliasing when using sparse field data (e.g. aerial photographs obtained every 3-5 years to determine long term recession), and the use of crude and inaccurate models (e.g. Bruun rule for SLR induced recession). Furthermore, the historical practice of defining setback lines based on a single deterministic estimate is also proving inadequate with the emergence of risk management style coastal planning frameworks which require probabilistic estimates of coastal erosion. This way of thinking is only now emerging in coastal management circles (Vrijling et al., 2002, Jongejan and Ransinghe, 2009, Van Dongeren et al, 2008).

The risk-informed approach presented in this paper builds on previous work by Vrijling et al. (2002) and Jongejan and Ranasinghe (2009). The proposed approach requires (time variant) probabilistic estimates of coastal erosion volumes. However, while the development of deterministic and semi-

${ }^{1}$ Jongejan Risk Management Consulting, Korvezeestraat 484, Delft, 2628DX, The Netherlands.

${ }^{2}$ Department of Civil Engineering and Geosciences, Delft University of Technology, Stevinweg 1, Delft, 2628 CN, The Netherlands.

${ }^{3}$ Department of Water Engineering, UNESCO-IHE, Westvest 7, Delft, 2601DA, The Netherlands; Department of Civil Engineering and Geosciences, Delft University of Technology, Stevinweg 1, Delft, 2628 CN, The Netherlands. 
probabilistic morphological models has always received considerable attention within the broader research community, the development of probabilistic approaches has only recently gained momentum in coastal engineering/management spheres (e.g. Ranasinghe and Stive, 2009; Ranasinghe et al., 2009; Van Dongeren et al, 2008; Callaghan et al., 2008; Cowell et al., 2006).

Callaghan et al. (2008) presented a probabilistic approach to determine the full range of dune erosion due to storms within a probabilistic framework (JPM model). This method makes use of marginal and conditional distributions fitted to long time series of wave data in conjunction with a process based dune erosion model to calculate the exceedance probabilities of dune erosion. The model output can be used to directly determine for example the 1 in $10 \mathrm{yr}$ or 1 in $100 \mathrm{yr}$ dune erosion volume at a given site. Similarly Ranasinghe et al (2009) presented a process based, probabilistic model (PCR model) to determine the exceedance probabilities of coastline recession due to sea level rise. This model represents a paradigm shift from the historically adopted Bruun rule approach of determining coastline recession due to SLR. The PCR model. which requires long term measurements of wave and water level data, can be directly used to determine for example the coastline recession value that is associated with an exceedance probability of $50 \%$ or $90 \%$.

To effectively use probabilistic estimates of the various contributors to coastal erosion in a risk based framework, it is necessary to differentiate between uncertainties that develop differently over time in the various different contributors. For example the uncertainty associated with short term storm erosion develops differently to that associated with long term recession due to SLR. This is due to different processes that govern these phenomena and/or due to the difference in current predictive capabilities for the different phenomena. Furthermore, risk based coastal management also requires that the economic value and lifetime of property/infrastructure developments be taken into account in arriving at optimal management strategies. These are two important aspects that are rarely taken into account in establishing coastal setback lines. This paper aims to generically demonstrate the effects of ignoring these aspects and proposes simple rules that can assist coastal planners/managers to determine coastal setback lines that optimise the balance between risk and reward.

\section{The economics of decision making under uncertainty}

The expected utility framework of Von Neumann and Morgenstern (1944) and Savage (1974) provides the basis for analyzing rational decisions under uncertainty, when only one out of a range of possible outcomes will eventually materialize. Von Neumann and Morgenstern (1944) and Savage (1974) construct a utility function that describes the preference ordering of a rational individual, and show that the individual, faced with uncertainty, ranks actions on the basis of the expected utility of their consequences. The idea that people maximize the expected utility of rewards rather than expected rewards themselves was first introduced by Bernoulli (1738).

Fig. 1 shows the utility functions of a risk averse and a risk neutral individual. A concave utility function corresponds to a decreasing marginal utility of wealth, meaning that the value (pleasure) that the individual attaches to an extra dollar decreases with his or her wealth so that greater weight is placed on losses than on gains. A risk averse individual is therefore averse to a gamble with a mean preserving spread. Put differently, for a risk averse individual, the cost of risk bearing exceed expected loss.

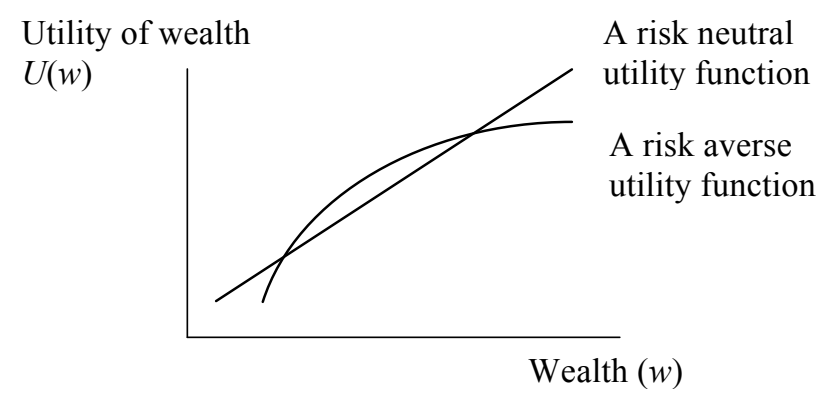

Figure 1. A risk-averse (concave) and risk neutral utility function. 
Because coastal zone risk is uncorrelated with the business cycle (it is a "zero beta" or diversifiable risk), the cost of risk bearing can be reduced to expected loss through risk sharing. When a large number of identical, uncorrelated risks are pooled in a single portfolio, the standard deviation of total loss will decrease relative to its mean value; expected loss is therefore often referred to as the actuarially fair insurance premium. Such pooling can be arranged through (re)insurance markets, capital markets (securitisation) or government insurance programs (governments pool a wide variety of risks, see also e.g. Arrow and Lind (1970)).

In the presence of an efficient risk-sharing arrangements, investments in risk mitigation can be evaluated through net present value computations with the cost of risk mitigation on the one hand, and expected loss (or: the actuarially fair insurance premium) on the other. This approach has been used in the Netherlands since the 1950s to inform decisions about flood protections (Fig. 2; Van Dantzig, 1956).

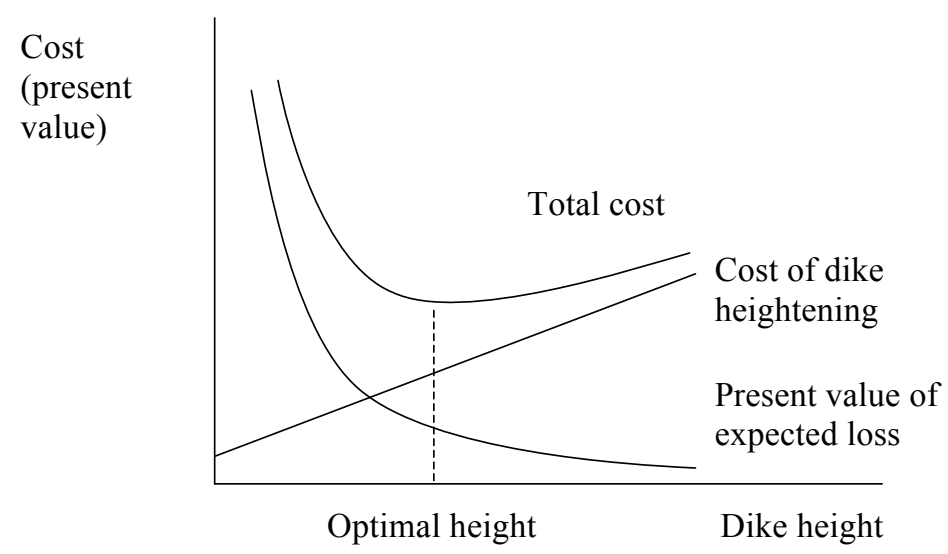

Figure 2. The optimisation of flood protection: total cost equals the cost of dike heightening plus the present value of expected loss (assuming stationary conditions: no sea level rise, economic growth or degradation).

\section{The economics of defining setback lines}

\section{Quantifying storm erosion risk}

Two inputs are needed for quantifying storm erosion risks: (i) an exceedance probability distribution of the extent of storm erosion, and (ii) a value density function that describes the spatial distribution of the value at risk (existing or planned) (Vrijling et al., 2002) (Fig. 3).
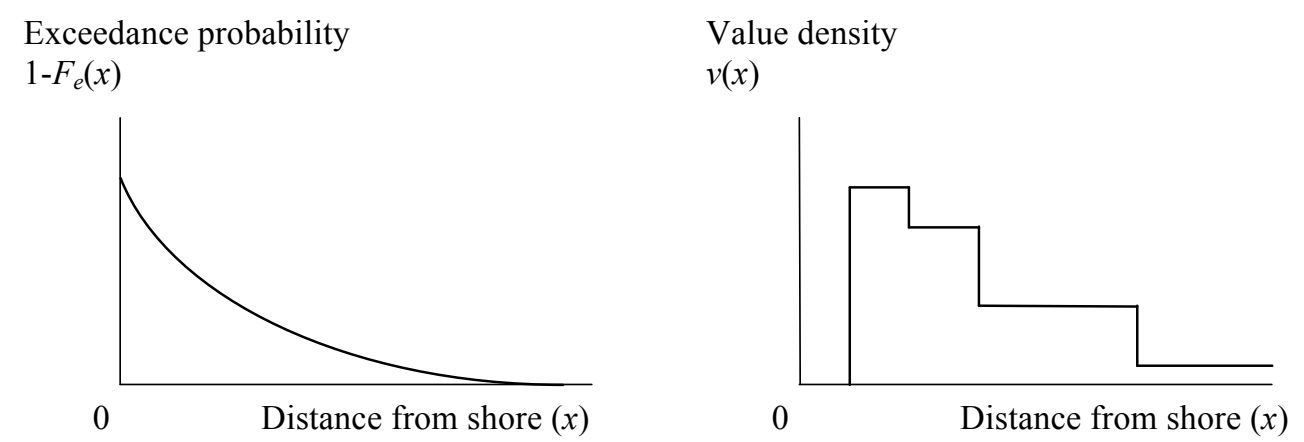

Figure 3. The exceedance probabilities of setback in $\mathrm{yr}^{-1} \mathrm{~m}^{-1}$ (left) and value density in euro/m $\mathrm{m}^{2}$ (right).

The probability of damage at a specific distance from shore $(P(x))$ equals the probability that storm erosion causes the shoreline to retreat beyond $x$ : 


$$
P(x)=1-F_{e}(x)
$$

The expected value of damage at a specific distance from shore $(E(d(x)))$ equals the product of the probability of damage and the value at risk at that location (assuming full damage):

$$
E(d(x))=\left(1-F_{e}(x)\right) \cdot v(x)=P(x) \cdot v(x)
$$

The expected value of damage per meter shoreline thus equals:

$$
E(d)=\int_{x=0}^{\infty}\left(1-F_{e}(x)\right) \cdot v(x) \cdot d x
$$

The exceedance probabilities of the extent of storm erosion $\left(1-F_{e}(x)\right)$ could be time-dependent due to sea level rise, changes in forcing and/or ambient long term trends in shoreline evolution. Because properties cannot be moved, this would cause loss probabilities to become time dependent, see fig. $4 \mathrm{a}$ and $4 \mathrm{~b}$.

\section{Time series}

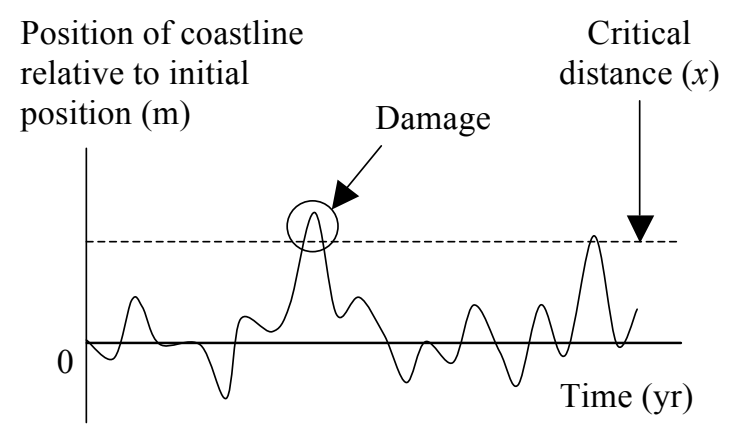

Top view

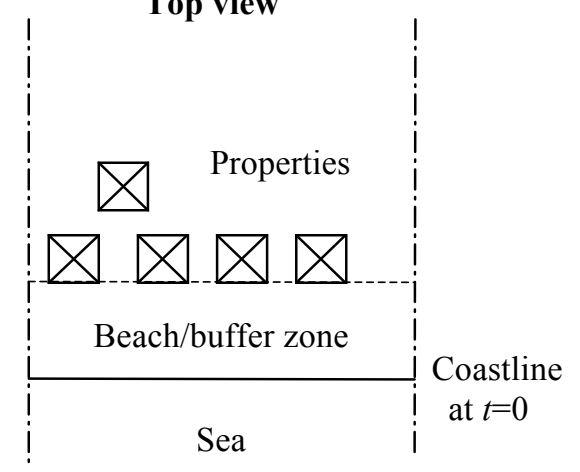

Figure 4a. A time series of coastal erosion for uncertain short-term erosion only (left) and a top view of the corresponding beach section (right).

\section{Time series}

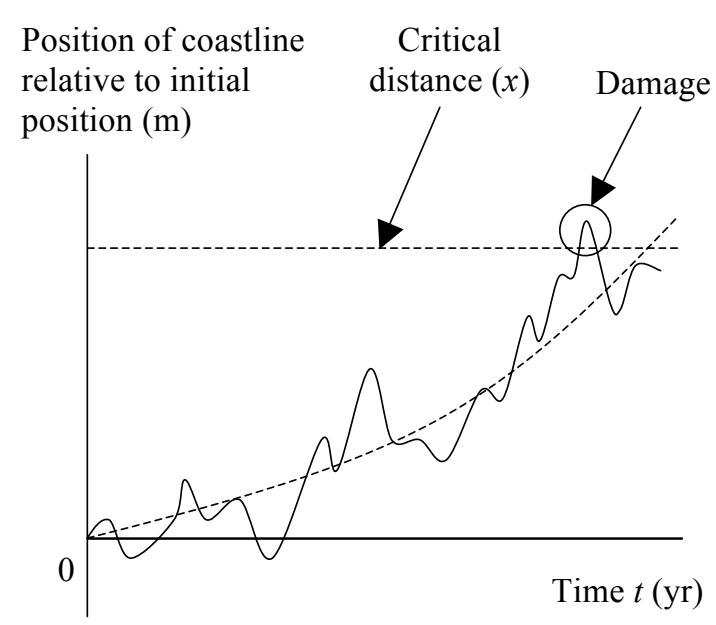

\section{Top view}

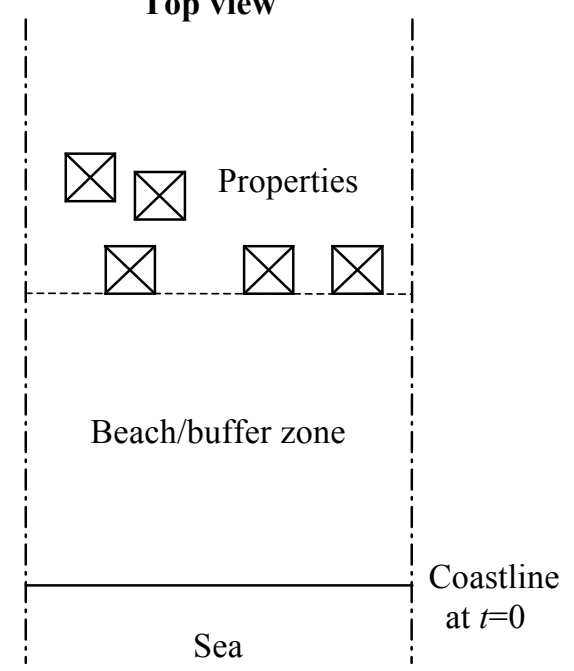

Figure 4b. A time series of coastal erosion for uncertain short term erosion plus a long-term trend (left) and a top view of the corresponding beach section (right). 


\section{Balancing risk and reward though the implementation of buffer zones}

In the absence of market imperfections, resources would be allocated efficiently by individuals and firms if they were left entirely to their own devices. From an economic perspective, there would then be little reason for government intervention, such as the implementation of buffer zones: buffer zones would naturally arise through private decisions concerning risk and reward. Note that this also means that the efficient position of a setback line can be found by analysing the behaviour of profit-seeking investors in a world without market imperfections.

In practice, explicit or implicit government guarantees (e.g. disaster funds, subsidized insurance schemes) and lack of knowledge about erosion risks may lead to overinvestment in coastal regions. The government could stem such overinvestment through the introduction of a compulsory insurance scheme, with premiums that reflect the probability of damage due to storm erosion. In case of efficiently priced insurance coverage, there would be little need for the implementation of setback lines as the cost of risk bearing would be factored into the investment decisions of individuals and firms. But when the government is unable to place the financial burden for (insurance against) storm erosion losses on those at risk, it could implement a zoning policy to avoid excessive risk-taking (unless such a policy would in itself be prohibitively costly).

While this paper deals solely with zoning policies, it is stressed that such policies will only be optimal in case of market imperfections, and that other types of interventions (e.g. compulsory insurance) might sometimes be even more appropriate. Throughout this paper, it is assumed that the government compensates those that suffer damage from storm erosion but is unable to collect a premium for its explicit or implicit guarantee. Under these conditions, a zoning policy could contribute to the efficient allocation of resources.

Establishing setback lines (safety zoning) is a means to mitigate the risks associated with coastal erosion. As shown in Fig. 3, the probability of damage is a decreasing function of the distance from shore. Hence, the farther a property is located from shore, the lower the probability that it will be damaged by erosion. But a greater safety zone also implies greater land-use opportunities forgone. Note that it is assumed throughout this paper that the value of land $(v(x))$ is a non-increasing function of the distance form shore $(x)$. Put differently: the closer to shore, the greater the reward (but also: the greater the risk).

\section{Case 1: efficient setback lines under stationary morphological conditions}

To analyse the efficiency of land-use decisions by private investors, we follow a cash-flow approach (hence, no depreciation) and assume that each investment is followed by a constant stream of net cashinflows:

$$
c(x)=r(x) \cdot I(x)
$$

where: $c(x)=$ net cash inflow per $\mathrm{m}^{2}$ at distance $x$ from shore (euro/yr $\left./ \mathrm{m}^{2}\right) ; I(x)=$ investment per $\mathrm{m}^{2}$ at distance $x$ from shore $\left(\right.$ euro $\left./ \mathrm{m}^{2}\right) ; r(x)=$ rate of return at distance $x$ from shore $\left(\mathrm{yr}^{-1}\right)$.

Under stationary morphological conditions, loss probabilities are constant over time. The net present value of an investment at a specific distance from shore then equals:

$$
N P V(x)=-I(x)+\int_{0}^{\infty} r(x) \cdot I(x) \cdot e^{-\gamma \cdot t} \cdot d t-\int_{0}^{\infty} P(x) \cdot I(x) \cdot e^{-\gamma \cdot t} \cdot d t
$$

where $N P V(x)=$ Net present value per $\mathrm{m}^{2}$ at distance $x$ from shore $\left(\right.$ euro $\left./ \mathrm{m}^{2}\right) ; r(x)=$ rate of return at distance $x$ from shore $\left(\mathrm{yr}^{-1}\right) ; I(x)=$ initial investment per $\mathrm{m}^{2}$ at distance $x$ from shore $\left(\mathrm{euro} / \mathrm{m}^{2}\right) ; P(x)=$ loss probability at distance $x$ from shore $\left(\mathrm{yr}^{-1}\right) ; \gamma=$ discount rate $\left(\mathrm{yr}^{-1}\right) ; t=$ time $(\mathrm{yr})$.

As long as the net present value is positive, the investment outperforms alternative investments with a similar risk profile (risk, here, refers to market risk, not storm erosion risk). When it equals zero, the investor will be indifferent to the investment in the coastal zone or the alternative investment. When it is negative, the investor will (should) not invest in the coastal zone. The net present value is negative if, and only if: 


$$
\int_{0}^{\infty} r(x) \cdot I(x) \cdot e^{-\gamma \cdot t} \cdot d t<\int_{0}^{\infty} P(x) \cdot I(x) \cdot e^{-\gamma \cdot t} \cdot d t+I(x)
$$

Or:

$$
\frac{r(x) \cdot I(x)}{\gamma}<\frac{P(x) \cdot I(x)}{\gamma}+I(x)
$$

Or:

$$
r(x)-\gamma<P(x)
$$

Hence, without market imperfections, no rational investor would invest in the zone between the shoreline and the setback line with an exceedance probability that equals the difference between the rate of return on investment and the cost of capital, i.e. the excess rate of return in the coastal zone (economic rent). If, say, investments in a coastal zone yield a $2,5 \%$ rate of return in excess of the rate of return offered by similar investments at inland locations $(r(x)+\gamma=0,025$ per year), the exceedance probability of the setback line that marks the contour of the buffer zone will equal 0,025 per year. ${ }^{4}$

Since the efficient position of a setback line can be found by analysing the behaviour of profit-seeking investors in a world without market imperfections, equation (8) also lays down the optimal position of a set-back line that is to be used for the demarcation of a buffer zone in case of market imperfections such as moral hazard or imperfection information. A buffer zone should be implemented up to the point where the difference between the rate of return on investment and the cost of capital (discount rate) equals the probability of damage.

\section{Case 2: Efficient setback lines under non-stationary morphological conditions}

The probability of damage might increase over time due to long term trends in coastline evolution and/or forcing. Under such circumstances, iso-risk contours will gradually move inland (Fig. 4b). Let us assume that the probability of damage increases annually by the same factor. The probability of damage at some time $t(p(x, t))$ then depends on today's probability of damage $\left(p_{0}(x)\right)$ according to:

$$
\begin{cases}p(x, t)=p_{0}(x) \cdot e^{a \cdot t} & \text { for } a \cdot t<-\ln \left(p_{0}(x)\right) \\ p(x, t)=1 & \text { for } a \cdot t \geq-\ln \left(p_{0}(x)\right)\end{cases}
$$

where $p_{0}(x)=$ probability of damage at distance $x$ from the shoreline at time $t=0\left(\mathrm{yr}^{-1}\right) ; a=$ constant $\left(\mathrm{yr}^{-}\right.$ $\left.{ }^{1}\right) ; t=$ time (yr).

Under the assumed time-dependency of the probability of damage, the actuarially fair insurance premium (expected loss) will start to exceed the annual return for properties that are located at some distance $x$ from today's shoreline, when:

$$
t=T^{*}= \begin{cases}\frac{1}{a} \cdot \ln \left(\frac{r(x)}{p_{0}(x)}\right) & \text { for } r(\mathrm{x}) \geq p_{0}(x) \\ 0 & \text { for } r(\mathrm{x})<p_{0}(x)\end{cases}
$$

Hence, the greater the margin between the rate of return and the probability damage, and the lower the intensity of the annual increase of the probability of damage, the longer it will take before the cost of risk bearing will exceed the return on investment. This is illustrated by Fig. 5. The figure shows the number of years it takes before risk exceeds return (vertical axis) as a function of the initial loss probability (horizontal axis), for different values of the number of years it takes for the probability of damage to increase by a factor $10\left(T_{10} ; T_{10}=1 / a \cdot \ln (10)\right)$.

\footnotetext{
${ }^{4}$ This results presented in this paper differ from the ones of previous studies (Vrijling et al., 2002); Jongejan and Ranasinghe, 2009) which failed to recognize the implications of the availability of alternative investment opportunities.
} 


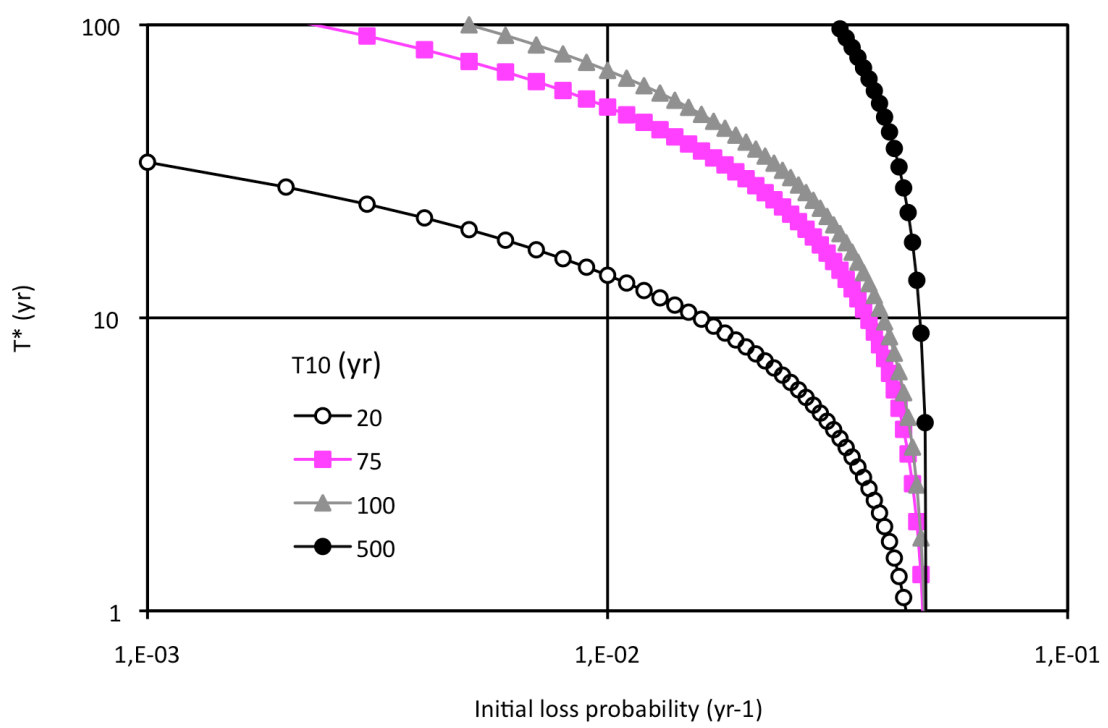

Figure 5. The expected number of years $\left(T^{\star}\right)$ it takes for the actuarially fair insurance premium to exceed the return on investment as a function of the initial loss probability, for different intensities of the long-term trend.

When probabilities of damage increase over time due to e.g. climate change, the cost of risk bearing will increase over time. When morphological conditions are non-stationary, the economic lifetimes of investments in coastal zones thus have to be considered. For non-stationary conditions, the net present value of an investment at some distance $x$ from today's shoreline can be computed according to:

$$
N P V(x)=\int_{0}^{T^{*}} r(x) \cdot I(x) \cdot e^{-\gamma \cdot t} \cdot d t-I(x)-\int_{0}^{T^{*}} P(x, t) \cdot I(x) \cdot e^{-\gamma \cdot t} \cdot d t
$$

where $N P V(x)=$ Net present value per $\mathrm{m}^{2}$ at distance $x$ from shore (euro $\left./ \mathrm{m}^{2}\right) ; r(x)=$ rate of return on investment at distance $x$ from shore $\left(\mathrm{yr}^{-1}\right) ; I(x)=$ initial investment per $\mathrm{m}^{2}$ at distance $x$ from shore $\left(\right.$ euro $\left./ \mathrm{m}^{2}\right) ; P(x, t)=$ Loss probability at distance $x$ from shore at time $t\left(\mathrm{yr}^{-1}\right) ; \gamma=$ discount rate $\left(\mathrm{yr}^{-1}\right) ; t=$ time $(\mathrm{yr}) ; T^{*}=$ economic lifetime $(\mathrm{yr})$.

Obviously, constructing a property with a technical lifetime that exceeds its economic lifetime $\left(T^{*}\right)$ is unnecessary, and, when it comes at a cost, constitutes a waste. When the probability of damage increases strongly, by e.g. a factor 10 every 20-50 years, the economic lifetime of a property development is about 35-50 years (assuming $\gamma=0,025 \mathrm{yr}^{-1} ; r(x)=0,05 \mathrm{yr}^{-1}$; fig. 6). For slower changes in the probability of damage, the economic lifetimes will be significantly higher however. 


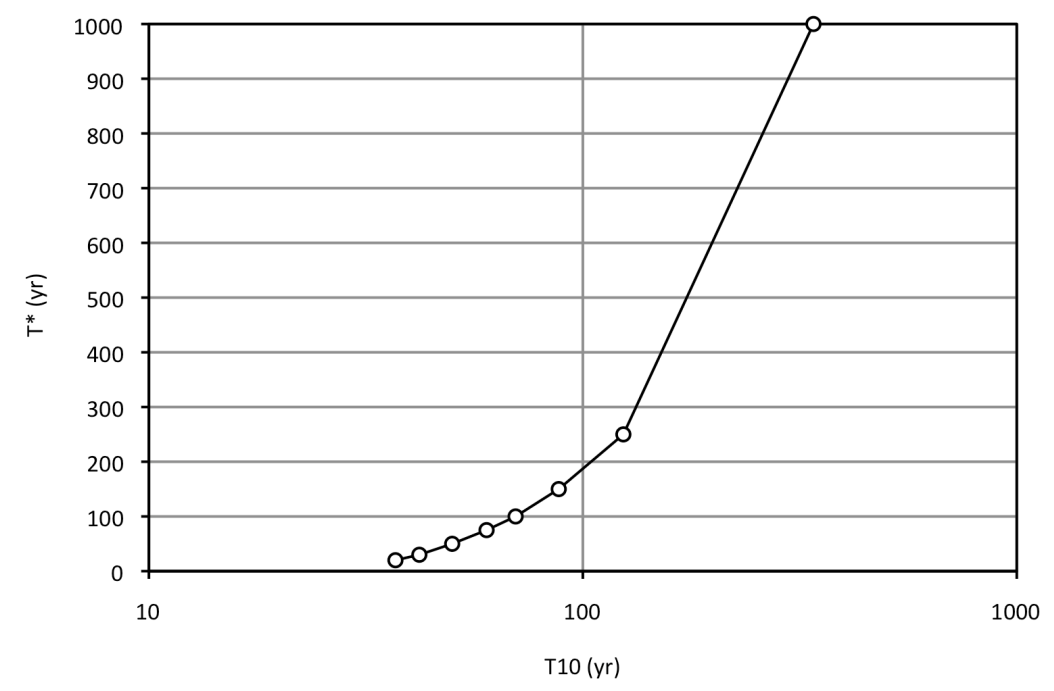

Figure 6. The number of years it takes for the actuarially fair insurance premium to exceed the return on investment $\left(T^{*}\right)$ as a function of the intensity of the long-term trend $\left(\gamma=0,025 \mathrm{yr}^{-1} ; \mathrm{r}(\mathbf{x})=0,05 \mathrm{yr}^{-1}\right)$.

Fig. 7 shows the normalised net present value per $\mathrm{m}^{2}(I(x)=1)$ of an investment at some distance $x$ from shore as a function of the initial annual probability of damage at that distance from shore. The greater the initial probability of damage, the greater the present value of expected loss and the lower the economic lifetime $\left(T^{*}\right)$, and hence, the lower the present value of cash inflows.

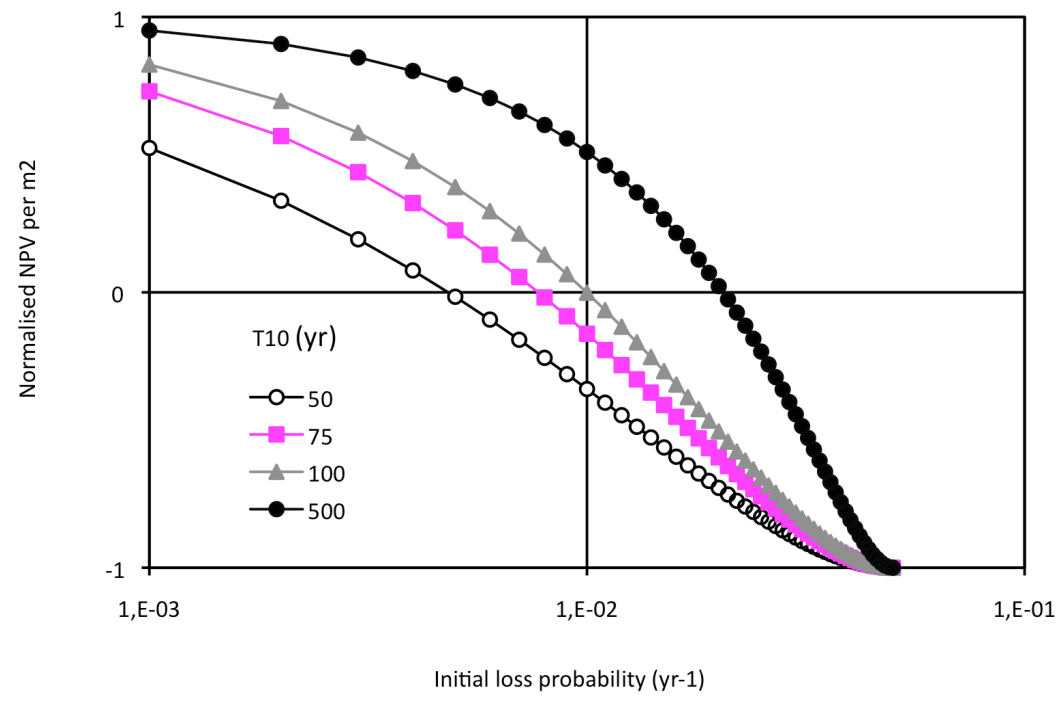

Figure 7. Normalised net present value per $\mathrm{m}^{2}$ as a function of the initial annual probability of damage for different intensities of the long-term trend $\left(\gamma=0,025 \mathrm{yr}^{-1} ; \mathrm{r}(\mathbf{x})=0,05 \mathrm{yr}^{-1}\right)$.

The optimal initial loss probability as a function of the number of years it takes for the probability of damage to increase by a factor $10\left(T_{10}\right)$ is shown in Fig. 8. For weak long term trends $\left(T_{10} \rightarrow \infty\right)$, the optimal initial loss probability asymptotically approaches the economic rent $r(x)-\gamma(x)$ (see also eq. 8). 


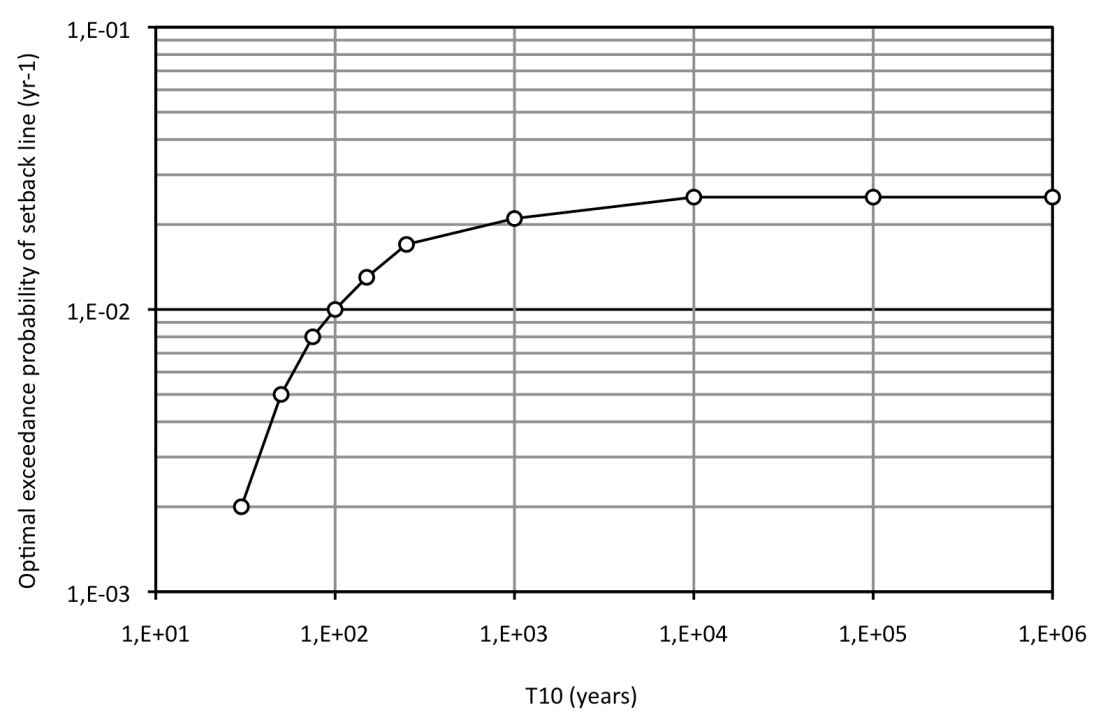

Figure 8. Optimal loss probability (or: optimal exceedance probability of the setback line that is used to define a buffer zone along a coast in case of e.g. moral hazard) as a function of the number of years it takes for this probability to increase by a factor $10\left(\gamma=0,025 \mathrm{yr}^{-1} ; \mathrm{r}(\mathrm{x})=0,05 \mathrm{yr}^{-1}\right)$.

As illustrated by Fig. 8, the exceedance probability of the economically optimal setback line (or: today's optimal probability of damage) only drops by a factor 5-10 when the intensity of the long-term trend is strong. This drop is even less pronounced in case of higher discount rates. Only when the probability of damage increases by a factor 10 every, say, 20-50 years, should a setback line with a significantly lower exceedance probability be selected for land-use planning purposes. The fact that only strong long-term trends significantly influence the optimal exceedance probability of the setback line is due to the fact that the present value of money earned today is greater than the present value of money earned in say 20 or 50 years (money earned today can be reinvested).

Eq. 9 assumes a deterministic (known/certain) trend. In reality, long-term shoreline evolution is subject to considerable uncertainty however. For example, ambient long term recession due to gradients in longshore transport is often estimated using aerial photographs obtained a few years apart. Hence the trend is determined using very few data points, which introduces significant uncertainty to these estimates. Similarly, recession due to SLR is often estimated by using the simple 2D mass conservation principle known as the Bruun Rule (Bruun, 1962), which produces recession estimates with a very high level of uncertainty (Ranasinghe and Stive, 2009). When long-term trends are uncertain, the parameter $a$ in eq. 9 (or $T_{10}$ ) is no longer a constant but a stochastic variable. Treating $a$ as a stochastic variable will however not significantly affect the results presented in this paper, given the relatively small influence of different (deterministic) long-term trends on today's investment decisions.

\section{Establishing setback lines: basic rules}

On the basis of the results of the preceding sections, relatively simple rules can be derived to assist coastal zone managers in dealing with land-use issues. The rules presented in Table 2 depend entirely on the costs and benefits of foregoing land-use opportunities. Considerations regarding e.g. public safety might lead to more stringent land-use regulations. It is emphasised that all parameter values mentioned in Table 2 are crude estimates that may vary depending on local circumstances. Moreover, it is emphasised that the implementation of buffer zones should only be considered in case of market imperfections that would otherwise lead to excessive risk-taking behaviour on the part of individuals and forms (due to e.g. moral hazard or lack of information) and that cannot be better resolved by other means (e.g. through the introduction of an insurance program). 


\begin{tabular}{|c|c|}
\hline Stationary morphological conditions & Non-stationary morphological conditions \\
\hline $\begin{array}{l}\text { Implement a buffer zone up to the point where the } \\
\text { probability of damage exceeds the rate of return on } \\
\text { investment minus the cost of capital, e.g. } 0,025 \mathrm{yr}^{-1} \text {. }\end{array}$ & $\begin{array}{l}\text { In case of small increases in the probabilities of } \\
\text { damage (e.g. by a factor } 10 \text { every }>100 \text { years): } \\
\text { - Implement a buffer zone up to the point (setback } \\
\text { line) where the probability of damage exceeds the } \\
\text { rate of return on investment minus the cost of } \\
\text { capital, e.g. } 0,025 \mathrm{yr}^{-1} \text {. } \\
\text { In case of moderate increases in the probabilities of } \\
\text { damage (e.g. by a factor } 10 \text { every } 50-100 \text { years): } \\
\text { - Reduce exceedance probability of the setback line } \\
\text { by a factor } 2 \text { (crude estimate). } \\
\text { - Select property types with technical lifetimes of } 50- \\
100 \text { years (crude estimate). } \\
\text { In case of very strong increases in the probabilities of } \\
\text { damage (e.g. by a factor } 10 \text { every } 20-50 \text { years): } \\
\text { - Reduce exceedance probability of the setback line } \\
\text { by a factor } 10 \text { (crude estimate). } \\
\text { - Select property types with technical lifetimes of } 25 \\
\text { to } 50 \text { years (crude estimate). }\end{array}$ \\
\hline
\end{tabular}

\section{Extensions: structural solutions and nourishment}

The results shown in Table 2 hold for a situation in which beach or shoreface nourishments and hard engineering solutions, such as breakwaters, are technically, environmentally and/or economically unfeasible. Since hard solutions and nourishments affect the probabilities of damage for entire alongshore beach segments, analysing the costs and benefits of these measures requires us to quantify net present values for entire beach segments (as done by Vrijling et al. (2002) for nourishments); simply analysing the tipping point where the net present value drops below zero (as done in this paper) will no longer suffice for these types of interventions.

While a full treatment of the efficiency of beach nourishments and structural solutions, possibly combined with restrictions on land-use (setback lines), is outside the scope of the present paper, the following observations could provide guidance to future work:

1. After a beach nourishment, the probability of damage will still drop from unity (on the shoreline) to zero (far inland). A beach nourishment program should thus always be combined with a landuse policy.

2. Under stationary morphological conditions, a beach nourishment simply changes the position of iso-risk contours. Hence, under stationary conditions, the rules for land-use planning presented in Table 2 will still hold after a nourishment. The costs and benefits of a beach nourishment (which is effectively a land-reclamation in case of stationary morphological conditions) can thus be evaluated in isolation.

3. Under non-stationary morphological conditions, beach nourishments can slow or even stop the landward shift of erosion contours over time. When stopping the landward shift is economically optimal (as it often will be, see Vrijling et al., 2002), the rules for land-use planning presented in the Table 2 for stationary morphological conditions should be followed.

4. When the implementation of a hard engineering solution, such as the construction of a breakwater, is efficient, the use of setback lines will no longer be necessary. The probability of storm erosion behind a breakwater is at maximum as high as the failure probability of the breakwater. When the probability of failure of a breakwater is lower than the economically optimal exceedance probability of the setback line that is used for land-use planning purposes, there will be no need to implement a buffer zone. This is because the exceedance probabilities of every setback line will be lower than the optimal value (if the probability of failure of the breakwater were higher than the economically optimal exceedance probability of the setback line, the breakwater would have no effect on the position of the erosion contours that matter for land-use planning). Put differently, hard engineering solutions and buffer zones are rival strategies: they should not be implemented simultaneously. 
Conclusions and recommendations

Foregoing land-use opportunities in coastal regions is costly, but so is damage caused by erosion. Defining appropriate setback lines for land-use planning is therefore a balancing act. The level of safety implied by current approaches could easily be too high or too low from an economic perspective. While setback lines are typically defined by their distance from shore or z-coordinate, it has been shown than it is more useful to define setback lines in terms of their exceedance probabilities.

The exceedance probabilities of economically optimal setback lines will typically be in the order of magnitude of $1 / 100$ per year, with minor corrections depending on local circumstances. It is emphasised that it is the order of magnitude of the exceedance probability that matters, not its exact value. The accuracy of probabilistic beach erosion models is such that probabilities may easily be overof underestimated by a factor 2-5. Moreover, a variation of the optimal exceedancy probabilitiy with a factor 2-5 will typically have only relatively little influence on the position of the setback line.

To develop economically optimal setback lines for specific locations, further work is needed to quantify the uncertainties related to short term storm erosion volumes, long term recession due to longshore transport gradients, and climate change impacts. However, while probability density functions of annual extremes (short-term) are a prerequisite for the implementation of the risk-informed approach, estimates of average long-term trends are likely to suffice in most cases. It may well prove feasible to develop economically optimal setback lines for categories of coastlines and types of coastal developments, to avoid having to design optimal setback lines on a case-by-case basis.

Further research is also needed to establish appropriate setback lines for situations in which nourishments are economically viable. Other than establishing setback lines that can accommodate future increases in loss probabilities, coastlines could be maintained at their present location by human intervention. This strategy is currently being successfully adopted in the Netherlands where the objective is to maintain the 1990 coastline via beach and shoreface nourishments.

\section{REFERENCES}

Arrow, K.J. and Lind, R.C. 1970. Uncertainty and the evaluation of public investment decisions, American Economic Review, 60(3): 364-378.

Bernoulli, D. 1738. Exposition of a new theory on the measurement of risk (original publication: 'Specimen Theoriae Novae de Mensura Sortis, Commentarii Academicae Imperialis Petropolitanas, Tomus V', Econometrica (1954), 22, 23-36.

Bruun, P. 1962. Sea-level rise as a cause of shore erosion, Journal of Waterways Harbors Division, 88: 117-130.

Callaghan, C., Nielsen, P., Short, A. and Ranasinghe, R. 2008. Statistical simulation of wave climate and extreme beach erosion, Coastal Engineering, 55(5): 375-390.

Cowell, P. J., Thom, B. G., Jones, R. A., Everts, C. H. and Simanovic, D. 2006. Management uncertainty in predicting climate change impacts on beaches, Journal of Coastal Research, 22: 232-245.

Ferreira, O., Garcia, T, Matias, A., Taborda, R., Alveirinho Dias, J. 2006. An integrated method for the determination of coastal setback lines for coastal erosion hazards on sandy shores, Continental Shelf Research, 26: 1030-1044.

Jongejan, R.B., Ranasinghe, R. (2009). Establishing setback lines for land-use planning: a riskinformed approach. Proceedings of Coasts and Ports 2009, Engineers Australia, Wellington, New Zealand.

Nicholls, R, J., Wong, P. P., Burkett, V. R., Codignotto, J. O., Hay, J. E., McLean, R. F., Ragoonaden, S. and Woodroffe, C. D. 2007. Coastal systems and low-lying areas. In ClimateChange 2007: Impacts, Adaptation and Vulnerability, Contribution of Working Group II to the Fourth Assessment Report of the Intergovernmental Panel on Climate Change, Cambridge University Press, Cambridge, UK.

Ranasinghe, R. and Stive, M. J. F. 2009. Rising Seas and Retreating Coastlines, Climatic Change (Editorial Commentary). DOI 10.1007/s10584-009-9593-3.

Ranasinghe, R, Callaghan, D. and Stive, M. J. F. 2009. A process based approach to derive probabilistic estimates of coastal recession due to sea level rise. Proceedings of Coastal Dynamics 2009, Tokyo, Japan (on CD Rom, World Scientific). 
Savage, L.J. (1974). The foundations of statistics, New York: Dover Publications Inc.

Van Dantzig, D. 1956. Economic decision problems for flood prevention, Econometrica, No. 24, 276287.

Van Dongeren, A.R., Boers, M., Diermanse, F.L.M., Van de Graaff, J., Van Koningsveld, M., Steetzel, H.J. 2008. Bepaling Beschermingscontouren Kustplaatsen, Resultaten voor de zeven Hollandse kustplaatsen (in Dutch). Deltares report H5016.

Von Neumann, J. and Morgenstern, O. 1944. Theory of games and economic behavior, Princeton University Press, Princeton.

Vrijling, J.K., Van Gelder, P., Litjes-Van Loon, J. 2002. Coastal zone risk in the Netherlands. Coastal Engineering 2002. Proceedings of the $28^{\text {th }}$ International Conference (7-12 July, Cardiff), 35083516. 